\title{
Lower Critical Solution Temperature in Aqueous Solutions of $N$-Alkyl-Substituted Polyacrylamides
}

\author{
Nikolai A. Platé, Tamara L. Lebedeva, ${ }^{\dagger}$ and Lev I. Valuev \\ A. V. Topchiev Institute of Petrochemical Synthesis, Russian Academy of Sciences, \\ Leninsky Prospect 29, Moscow 117912, Russia
}

(Received March 20, 1998)

\begin{abstract}
The structures and properties of $N$-alkyl-substituted polyacrylamides (PAA) were studied by FT-IR spectroscopy. For $N$-alkyl-substituted PAA with lower critical solution temperature (LCST), a specific H-bonded cyclic structure involving alkyl amide units of a polymer and hydroxyl functions of water was observed and found responsible for polymer solubility. The mechanism for the appearance of a LCST in aqueous solution of $N$-alkyl-substituted PAA is discussed and factors of position of LCST are examined.

KEY WORDS N-Alkyl-Substituted Polyacrylamides / Aqueous Solutions / Lower Critical Solution

Temperature / H-Bonds / Conformational Analysis / Fourier Transform Infrared Spectroscopy /
\end{abstract}

Many polymers in aqueous solution show a lower critical solution temperature (LCST). LCST in a polar system, such as polymer-water, is accompanied by strong dipole-dipole interactions or $\mathrm{H}$-bond formation between components.

$N$-alkyl-substituted polyacrylamide (PAA) is a typical example of polymers having a LCST ${ }^{1}$ (Table I). Solutions of $\operatorname{poly}(N$-isopropyl acrylamide) (PIPAA) have been studied most thoroughly. ${ }^{2-7}$ Jehudah $^{2}$ concluded that dissolution of PIPAA in water results in "disguised" H-bonded structures, not formed when unsubstituted PAA is dissolved. Breaking up these structures (by adding $\mathrm{LiCl}$ or urea) decreases the LCST of PIPAA, but does not affect the intrinsic viscosity of the PAA solution. From the view point of effects of urea on polymer solubility, PIPAA is similar to poly(methacrylic acid) (PMAc) and poly (methacrylamide) (PMA).

However, the solubility of PIPAA in water significantly increases when sodium dodecylsulphonate $\left(\mathrm{C}_{12}\right.$ $\mathrm{H}_{25} \mathrm{SO}_{2} \mathrm{ONa}$ ) is added, due to hydrophobic bonding. PMAc, polyacrylic acid, and PVA, unlike PAA and PMA, which do not interact with $\mathrm{C}_{12} \mathrm{H}_{25} \mathrm{SO}_{2} \mathrm{ONa}$, show similar behavior. ${ }^{2}$

The formation of stable $\mathrm{H}$-bonded dimers in solutions of polycarboxylic acids ${ }^{8}$ and H-bonded "polymer" in solutions of polyalcohols ${ }^{9}$ leads to the stabilization of the trans-zigzag conformation of the main chain, resulting in more complete segregation between hydrophobic and hydrophilic segments of a polymer. For PAA and PMA, the formation of intramolecular $\mathrm{H}$ bonds between the amide groups of the neighboring units $^{10}$ results in twisting of the main chain wherein the amide groups "protect" them from the outside. In this case, hydrophobic and hydrophilic segments of a polymer are far from being completely segregated.

Thus, the existence of LCST in aqueous solutions of $N$-alkyl-substituted PAA is associated with the ability to form disguised $\mathrm{H}$-bonded structures controlling the solubility of a polymer and effects of hydrophobic segments in the polymer resulting in insolubility of a polymer upon deterioration of $\mathrm{H}$-bonded structures.

\footnotetext{
† To whom correspondence should be addressed.
}

Not all $N$-alkyl-substituted PAA display LCST, although all are inclined to H-bond formation (see Table I).

The specific influence of different fragments of polymer molecules and solvent in the formation of various complexes and aggregates may be best examined using spectroscopic techniques. This study used FT-IR spectroscopy to investigate the structures and properties of $\mathrm{N}$-alkyl-substituted PAA and their aqueous solutions. Two systems with LCST [PIPAA and $\operatorname{poly}(N$ diethyl acrylamide)] and two model systems without

Table I. LCST in aqueous solutions of $N$-alkyl-substituted PAA and PMA (literature data ${ }^{1}$ )

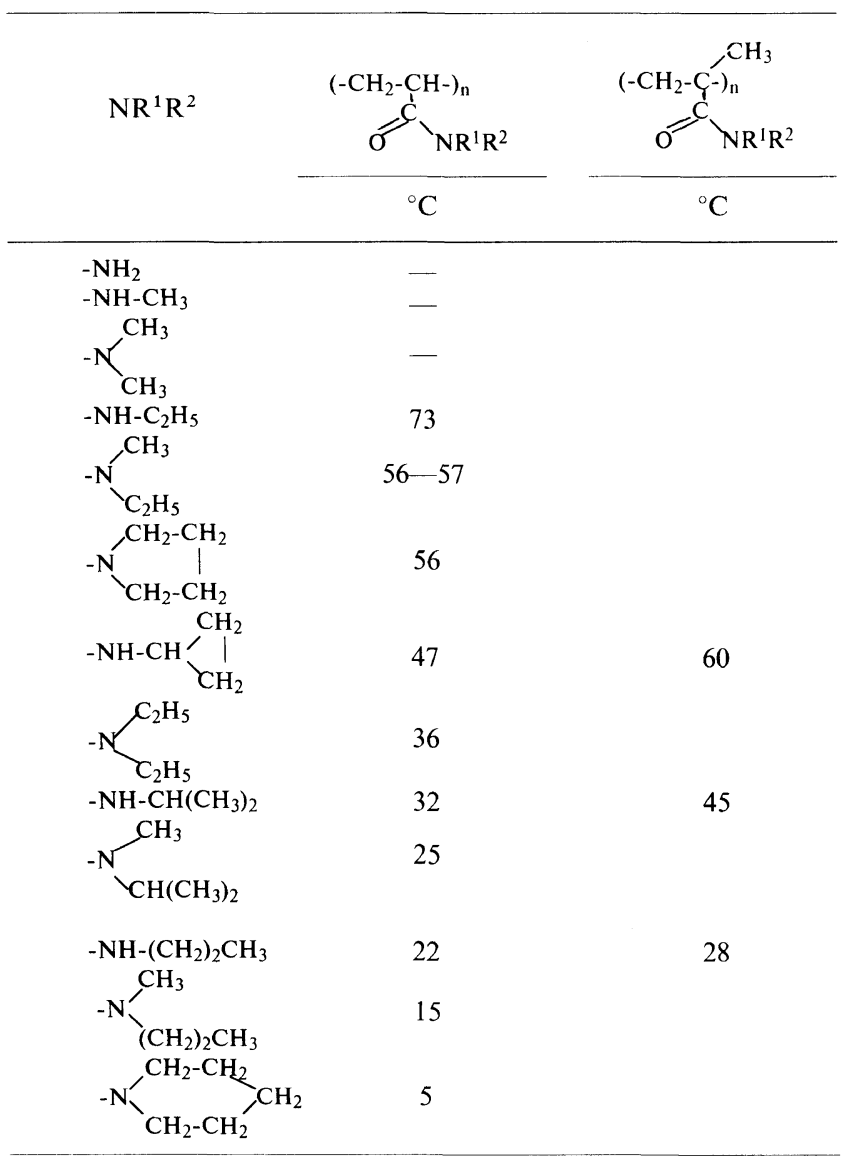


Table II. Basic bands in the FT-IR-spectra of solid samples of PAA and $N$-alkyl-substituted PAA, $\mathrm{cm}^{-1}$

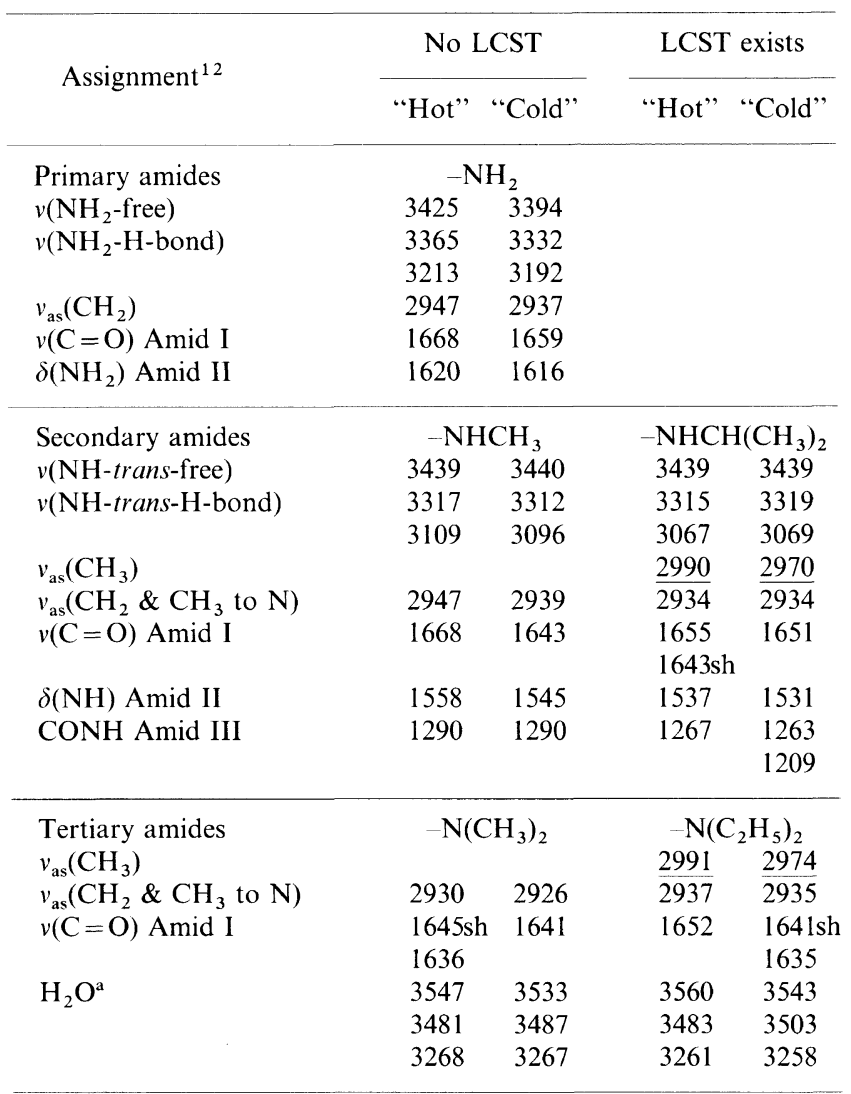

${ }^{a}$ For primary and secondary amides, bands due to water are hidden by stretching vibrations of $\mathrm{NH}_{2}$ and $\mathrm{NH}$ groups.

LCST $[\operatorname{poly}(N$-methyl acrylamide) and poly $(N$-dimethyl acrylamide)] were studied.

\section{EXPERIMENTAL}

PAA and $N$-alkyl-substituted PAA were synthesized using a modified procedure described in ref 11 .

FT-IR spectra were recorded with an IFS-113v (Bruker) spectrometer. Solid polymer samples were prepared by casting from $2 \%$ aqueous solutions of the corresponding polymers followed by thermal treatment as shown on the Figure 1. A $5 \mu \mathrm{m}$ thick and thermostated $50 \mu \mathrm{m}$ thick $\mathrm{CaF}_{2}$ IR-cell were used for investigating aqueous solutions of $N$-alkyl-substituted PAA.

\section{RESULTS}

Analysis of the FT-IR spectra of "Cold" and "Hot" solid samples of PAA and $N$-alkyl-substituted PAA (see Table II), as well as of substraction spectra, revealed that amide groups are actively involved in $\mathrm{H}$-bond formation. Changes in the spectra of "Hot" and "Cold" samples of polymers with and without LCST differed.

In LCST polymers $v_{\text {as }}\left(\mathrm{CH}_{3}\right)$ shifts from 2990 to $2970 \mathrm{~cm}^{-1}$. A significant shift (by $20 \mathrm{~cm}^{-1}$ ) of the band due to valence vibrations of $\mathrm{CH}_{3}$ group appears to be a feature of principal interest. Taking into account that in the "Cold" sample the intensity of the band concomitantly decreases, due to decreased polarization of the bond, ${ }^{12}$ one finds strong reasons to assume the existence in the "Cold" samples of the structure with "disguised" H-bond of the type,<smiles>[R11]N(C[CH])C(=O)[C@H](CCCC)CCCCC</smiles>

The formation of such a six-membered ring should stabilize the enolic form of the amide group and decrease the hydrophobicity of the alkyl radical.

For $N$-ethyl acetamide, as a model structure, we performed complete optimization of the geometry of all plausible conformers<smiles>CCCCCC(C)=O</smiles>

1<smiles>CCCCCC(C)=O</smiles><smiles>CC(=O)NCCc1ccccc1</smiles>

3 using Hartree-Fock (SCF) formalism in AM1 approximation.

Structure 1 is by $7.79 \mathrm{~kJ} \mathrm{~mol}^{-1}$ more favorable than structure 2. The energy of structure $\mathbf{3}$ was close to that of 1. According FT-IR data (Table II) secondary amides exist only in the trans-conformation.

In structure 1, the $\mathrm{CH}_{3}$ group, inclined at an angle of $30^{\circ}$ with respect to the plane of the ring is incapable of forming a H-bond. However, the bonds are strongly polarized, giving rise to electrostatic interactions between $\mathrm{C}=\mathrm{O}$ and $\mathrm{CH}_{3}$ groups.

These results coincide with quantum chemical computations carried out for $t$-butyl acetate ${ }^{13}$ for which it was demonstrated that, when the $\mathrm{CH}_{3}$ group approaches the $\mathrm{C}=\mathrm{O}$ group (rotation by $30^{\circ}$ around the $\mathrm{C}-\mathrm{O}$ bond), the $\mathrm{O} \cdots \mathrm{H}$ bond index increases twofold reaching the level of a common $\mathrm{H}$-bond. These $\mathrm{H}$-bonds are not stable because they are present in a nonequilibrium molecular structure.

Taking into account that the solid sample contains solvating water, a somewhat different structure may exist:<smiles>CC(=O)CCCCO</smiles>

For this model structure we also performed complete optimization of the geometry. As demonstrated by quantum chemical computations, this is an optimal structure. Although the $\mathrm{CH}_{3}$ group is inclined at an angle of $30^{\circ}$, this structure involves two $\mathrm{H}$-bonds: $\mathrm{C}=\mathrm{O} \cdots$ $\mathrm{H}-\mathrm{O}$ and $\mathrm{H}-\mathrm{O} \cdots \mathrm{H}-\mathrm{C}$ with the bond indexes of -0.1618 
A

B
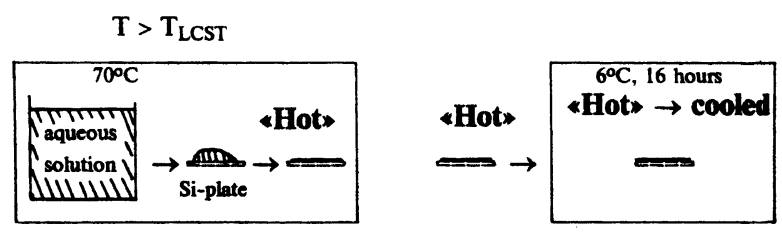

$$
\mathrm{T}<\mathrm{T}_{\mathrm{LCST}}
$$
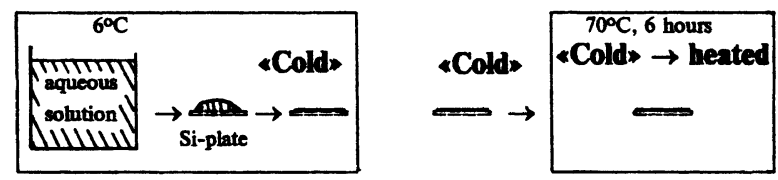

Figure 1. Preparation (A) and temperature treatment (B) polymer solid samples for FT-IR.

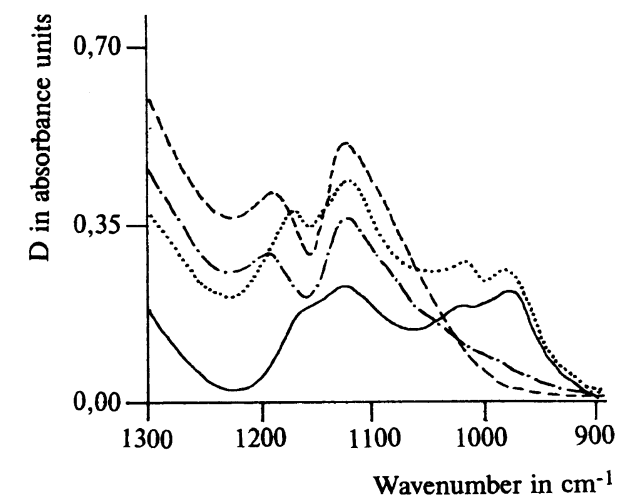

Figure 2. FT-IR spectra of solid samples of non-substituted PAA: "Hot" (- $(-$,Cold" $(---)$, "Cold" $\rightarrow$ heated $(\cdots . .$.$) and "Hot" \rightarrow$ cooled $(-\cdot-\cdot-\cdot-)$.

and -0.1103 , respectively.

These results are similar to those from the $\mathrm{X}$-ray study of the cephadroxil monohydrate $\left(\mathrm{C}_{16} \mathrm{H}_{17} \mathrm{~N}_{3} \mathrm{O}_{5} \mathrm{~S}\right.$. $\mathrm{H}_{2} \mathrm{O}$ ). ${ }^{14}$ Although the distance between the nitrogen atom in amine and oxygen in the amide is about $0.27 \mathrm{~nm}$, no common intramolecular $\mathrm{H}$-bond is formed. The atoms $\mathrm{N}$ and $\mathrm{O}$ are linked with two $\mathrm{H}$-bonds through the water molecule:

$$
>\mathrm{N}-\mathrm{H} \ldots \mathrm{O}-\mathrm{H} \ldots \mathrm{O}=\mathrm{C}<.
$$

There is experimental proof of the existence of the $\mathrm{H}$-bonded cyclic structure in "Cold" samples of $\mathrm{N}$ alkyl-substituted PAA. After thermal treatment (Figure 1) of the solid sample ("Hot" or "Cold") its FT-IR spectrum (see, for example, Figure 2) showed bands characteristic of the opposite sample ('Cold" or "Hot", conformably) and was the superposition of the two spectra:

or

$$
\text { "Hot" } \rightarrow \text { cooled }=X \text { "Hot" }+Y \text { "Cold" }
$$

$$
\text { "Cold" } \rightarrow \text { heated }=X \text { "Cold" }+Y \text { "Hot". }
$$

Hence the coefficient $X$ is the relative quota of the initial structure intact in the solid sample after treatment (Table III). As evident from Table III after cooling the "Hot" samples, their structures were partly transformed,
Table III. Relative quota of the intact initial structure of polymer after treatment of "Hot" and "Cold" samples of $N$-alkyl-substituted PAA (coefficients $(X+0.02)$

\begin{tabular}{|c|c|c|c|}
\hline \multirow[b]{2}{*}{ Sample } & \multicolumn{3}{|c|}{ No LCST } \\
\hline & $-\mathrm{NH}_{2}$ & $-\mathrm{NHCH}_{3}$ & $\mathrm{~N}\left(\mathrm{CH}_{3}\right)_{2}$ \\
\hline "Hot" $\rightarrow$ cooled & 0.28 & 0.29 & 0.44 \\
\hline \multirow{2}{*}{ "Cold" $\rightarrow$ heated } & 0.39 & 0.46 & 0.46 \\
\hline & \multicolumn{3}{|c|}{ LCST exists } \\
\hline Sample & $-\mathrm{NHCH}\left(\mathrm{CH}_{3}\right)_{2}$ & & $-\mathrm{N}\left(\mathrm{C}_{2} \mathrm{H}_{5}\right)_{2}$ \\
\hline "Hot" $\rightarrow$ cooled & 0.71 & & 0.66 \\
\hline "Cold" $\rightarrow$ heated & 0.94 & & 0.90 \\
\hline
\end{tabular}
of FT-IR-spectra subtraction in $4000400 \mathrm{~cm}^{-1}$ range)

("Hot" $\rightarrow$ cooled)-X"Hot" or ("Cold" $\rightarrow$ heated)-X"Cold"

Table IV. Relative thickness, $d{ }$ "Cold ${ }^{\prime} / d{ }$ Hot" $( \pm 0.05)$,

\begin{tabular}{|c|c|c|c|}
\hline \multirow[b]{2}{*}{ Sample } & \multicolumn{3}{|c|}{ No LCST } \\
\hline & $-\mathrm{NH}_{2}$ & $-\mathrm{NHCH}_{3}$ & $-\mathrm{N}\left(\mathrm{CH}_{3}\right)_{2}$ \\
\hline "Hot" $\rightarrow$ cooled & 0.57 & 0.37 & 0.91 \\
\hline \multirow[t]{2}{*}{ "Cold" $\rightarrow$ heated } & 0.64 & 0.48 & 0.87 \\
\hline & \multicolumn{3}{|c|}{ LCST exists } \\
\hline Sample & $-\mathrm{NHCH}\left(\mathrm{CH}_{3}\right)_{2}$ & & $-\mathrm{N}\left(\mathrm{C}_{2} \mathrm{H}_{5}\right)_{2}$ \\
\hline "Hot" $\rightarrow$ cooled & 1.59 & & 1.21 \\
\hline "Cold" $\rightarrow$ heated & 1.67 & & 1.20 \\
\hline
\end{tabular}
of solid samples of $N$-alkyl-substituted PAA, determined from heat-treatment mediated IR-transparency variation (each sample)

whereas heating the "Cold" sample caust the opposite visible effect only in polymers without LCST (Table III, Figure 2).

After thermal treatment of the all solid samples IRtransparency changed. For solid samples this may be related only to sample thickness. Therefore, one can assess the temperature-induced variation of sample thickness (with an account for partial recovery-Table III). The data summarized in Table IV reveal that polymers without LCST behave as common solid bodies; that is, they expand on heating, and contract on cooling. The situation is different with polymers showing LCST: "Cold" samples become looser. This is related to the formation, at low temperatures, of stable H-bonded structures preventing dense packing. In the case under consideration the loose structure is most likely associated with specific $\mathrm{H}$-bonded structure $\mathbf{4}$ rather than with the system of amide $\mathrm{H}$-bonds present in all polymers of this type.

Apparently, the specific $\mathrm{H}$-bonded structure $\mathbf{4}$ prevails in "Cold" samples prepared from homogeneous aqueous solutions.

For this reason the FT-IR spectra of aqueous solutions of polymers with LCST were studied in detail. But FTIR spectra of water (bi-distillate, $\mathrm{pH}=7.00 \pm 0.03$ ) were studied for comparison (Figure 3). FT-IR spectra for thin and thick water layers are different. Since the 


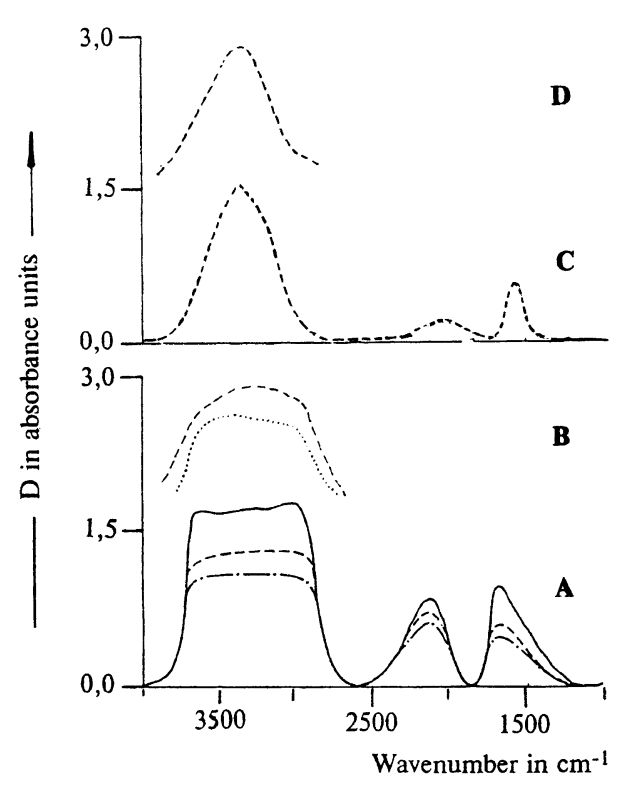

Figure 3. FT-IR spectra of water $(\mathbf{A}, \mathbf{C})$ measured at $15^{\circ} \mathrm{C}(-)$, $25^{\circ} \mathrm{C}(-\cdots)$, and $35^{\circ} \mathrm{C}(-\cdot-\cdot \cdot-)$ in $50 \mu \mathrm{m}(\mathbf{A})$ and $5 \mu \mathrm{m}(\mathbf{C})$ thick cells and Raman spectra (data of ref 19) of water $(B)$ and saturated $\mathrm{NaCl}$ aqueous solution (D) measured at $27^{\circ} \mathrm{C}(----)$ and $77^{\circ} \mathrm{C}(\cdots \cdots)$ in $100 \mu \mathrm{m}$ thick cell.

structure of water significantly changes on water contact with other molecules. This change affects many other water molecules which have no such contact (second hydrate layer). ${ }^{15}$ Thus, the thinner the layer between solid windows the higher is the concentration of water molecules with structures different from those in water bulk.

The FT-IR spectrum for thin water layer (Figure 3 ) is similar to the published IR-spectra. ${ }^{16-19}$ As concerns the thick water layers IR-spectra and discussion of the $v_{\mathrm{OH}}$ region, they are usually omitted in the literature.

Since water is a strongly associated liquid, Raman- and IR-spectra coincide because of the breakdown of vibrational selection.

In Figure 3, IR-spectra for thick water layer obtained are similar to known Raman-spectra for thick water layer (with sample thickness not less than $100 \mu \mathrm{m}$ ), ${ }^{20}$ while the FT-IR spectra for thin layer are similar with published Raman-spectra for thick layers of saturated salt solutions, in which there is practically no pure water. The temperature dependence of the water FT-IR spectra and published Raman-spectra (Figure 3) corroborates the correctness of our data. The lower the temperature the stronger are $\mathrm{H}$-bonds and the more is $\mathrm{O}-\mathrm{H}$ band polarization and as a result the more the $v_{\mathrm{OH}}$ intensity.

IR-spectrum in the $v_{\mathrm{OH}}$ region cannot be presented by only one single band due to the rather heterogeneous structure of water. ${ }^{17,18}$ Indeed, even in thin water layer spectra one can notice fine distinct structures of the $v_{\mathrm{OH}}$-band consisting of at least three components: $3210 \mathrm{~cm}^{-1}$ - the ice-like structure constructions; 3450 $\mathrm{cm}^{-1}$ - the twisted ice-like structure constructions; $3620 \mathrm{~cm}^{-1}$ - slightly $\mathrm{H}$-bonded water molecules in the spare volume of the ice-like structure construction. ${ }^{20}$ The temperature dependence of the water FT-IR and Raman-spectra (Figure 3) is in accordance with this assignment.

The FT-IR spectra for thick layers of $1 \mathrm{wt} \%$ aqueous

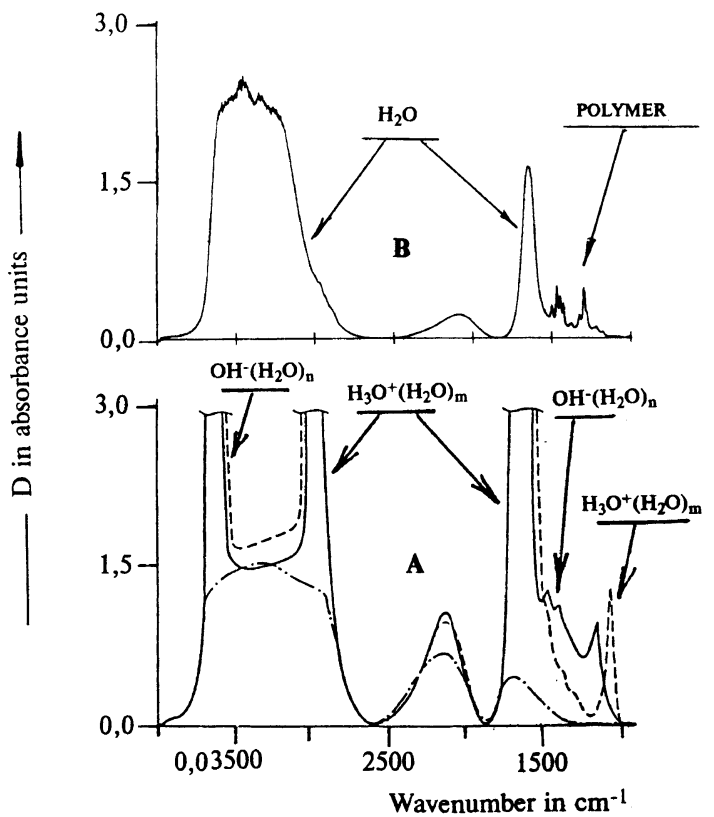

Figure 4. FT-IR spectra of $1 \mathrm{wt} \%$ (A) and $15 \mathrm{wt} \%$ (B) aqueous solutions of poly $(\mathrm{N}$-diethyl acrylamide $)$ measured at $15^{\circ} \mathrm{C}(-), 25^{\circ} \mathrm{C}$ $(---)$, and $35^{\circ} \mathrm{C}(-\cdot \cdot \cdot \cdot-)$ in $50 \mu \mathrm{m}$ thick cell

solutions of polymers with LCST (for example, Figure 4 and Table V) demonstrate that below LCST there are new bands in the region $1500-1000 \mathrm{~cm}^{-1}$ of the FT-IR spectra. Above LCST these bands disappear, but when the temperture decreases these bands appear again. This effect in FT-IR spectra for the thick layers of $15 \mathrm{wt} \%$ aqueous solutions (heterogeneous gel like) of polymers is considerably less (Figure 4) and in FT-IR spectra for thin aqueous solutions layers is absent.

The polymer bands in the FT-IR spectra of $1 \mathrm{wt} \%$ aqueous solutions of polymer are not seen, because their intensity is much less than the water band intensity. Hence the observed phenomenon is based on temperature changes of structures of large water clusters. Liquid water is characterized by several structural changes at 15,30 , 45 , and $60^{\circ} \mathrm{C},{ }^{21}$ but these changes are not manifest in FT-IR spectra so distinctly (Figure 3 ).

Analysis of FT-IR spectra shows that at low temperature homogeneous solutions contain a lot of $\mathrm{OH}^{-}\left(\mathrm{H}_{2} \mathrm{O}\right)_{n}$ and $\mathrm{H}_{3} \mathrm{O}^{+}\left(\mathrm{H}_{2} \mathrm{O}\right)_{m}$ ions (about $15 \mathrm{~mol} \%$ ), practically absent in pure water. IR spectra of these ions ${ }^{16,22-25}$ (Table V) are much more intense than the spectra of the dissolved polymer and pure water (Figure $3)$. Assignments of such bands in the IR-spectra of the $\mathrm{HCl}$ and the $\mathrm{KOH}$ aqueous solutions contained $\mathrm{H}_{3} \mathrm{O}^{+}$ and $\mathrm{OH}^{-}$ions hydrates are discussed in detail. ${ }^{16}$

Thus, in a system comprising a nonionogenic polymer and water, ionic fragments appear, indicating polymerinduced dissociation of water and binding the $\mathrm{OH}^{-}$and $\mathrm{H}_{3} \mathrm{O}^{+}$ions by a polymer with $\mathrm{H}$-bonds (Table V). Ion fragments of water are inserted into the macromolecular structure and polymer dissolution increases. H-bonds between ion fragments of water and polymer are strengthened with decreasing temperature and are weaker-increasing temperature, leading to ion water structure disappearance (Figure 4). The ion water structure consists of many water molecules, from which only two molecules are connected with a polymer directly. 
Table V. Frequencies of main bands in FT-IR spectra of aqueous solution of poly $\left(N\right.$-diethyl acrylamide) and water, $\mathrm{cm}^{-1}$

\begin{tabular}{|c|c|c|c|c|c|c|c|c|}
\hline \multirow{2}{*}{$\begin{array}{l}\text { Assignment } \\
\text { ref } 12 \text { and } 22\end{array}$} & \multicolumn{2}{|c|}{$\begin{array}{l}\text { Solution of } \\
\text { poly( } N \text {-diethyl } \\
\text { acrylamide) }\end{array}$} & \multicolumn{2}{|c|}{$\mathrm{H}_{2} \mathrm{O}$} & \multirow{2}{*}{$\begin{array}{c}\mathrm{H}_{3} \mathrm{O}^{+} \\
\text {ref } 16,23 \text {, and } 24\end{array}$} & \multirow{2}{*}{$\begin{array}{l}\mathrm{H}_{3} \mathrm{O}^{+} \cdot \mathrm{ClO}_{4}^{-} \\
\text {ref } 22 \text { and } 25\end{array}$} & \multirow{2}{*}{$\begin{array}{c}\mathrm{OH}^{-} \\
\text {ref } 16 \text { and } 22\end{array}$} & \multirow{2}{*}{$\begin{array}{l}\mathrm{Mt}-\mathrm{OH}^{\mathrm{a}} \\
\text { ref } 22 \text { and } 23\end{array}$} \\
\hline & $15^{\circ} \mathrm{C}$ & $23^{\circ} \mathrm{C}$ & $15^{\circ} \mathrm{C}$ & $23^{\circ} \mathrm{C}$ & & & & \\
\hline \multirow[t]{3}{*}{$v(\mathrm{OH})$} & 3707 & 3703 & & & & & $3700-3500$ & $3700-3680$ \\
\hline & & & $\begin{array}{l}3650- \\
3000\end{array}$ & $\begin{array}{l}3600- \\
2900\end{array}$ & & & & \\
\hline & 3037 & 3063 & & & $3500-3000$ & $3390-2960$ & & \\
\hline \multirow[t]{2}{*}{ Overtone } & & & 2151 & 2154 & & & & \\
\hline & 2133 & 2127 & & & 2120 & & & \\
\hline \multirow[t]{7}{*}{$\delta(\mathrm{OH})$} & & 1720 & & & 1700 & & & \\
\hline & & & 1690 & 1690 & & & & \\
\hline & 1600 & & & & & 1590 & & \\
\hline & 1460 & & & & & & & $1470-1400$ \\
\hline & 1440 & & & & & & & \\
\hline & 1145 & & & & & 1150 & & \\
\hline & & 1064 & & & 1060 & & & \\
\hline
\end{tabular}

${ }^{a}$ In complexes with metals with $\mathrm{OH}$ present in the tetrahedral structure.

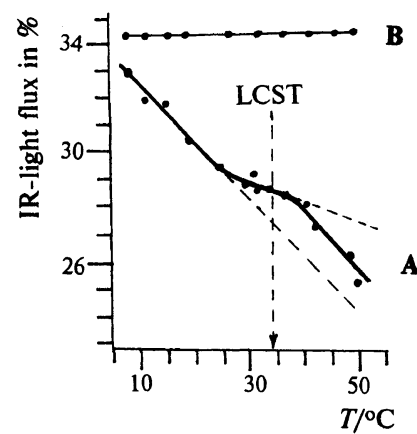

Figure 5. Temperature dependence of IR-transparency (amplitude of IR-light signals at $\left.4000-400 \mathrm{~cm}^{-1}\right)$ of the $1 \mathrm{wt} \%$ aqueous solution of poly $(N$-diethyl acrylamide) (A) and water $(\mathbf{B})$.

This is illustrated as follows:

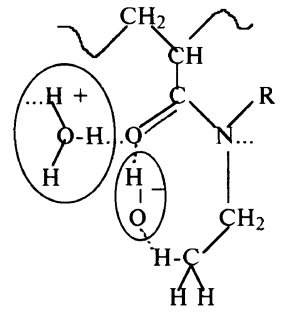

5

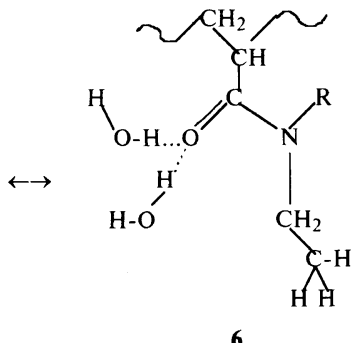

6
At room temperature the $\mathrm{pH}$ aqueous solutions of PIPAA and poly $(N$-diethyl acrylamide $)$ are $7.5 \pm 0.03$ and $6.8 \pm 0.03$, whereas those of aqueous solutions of $N$-alkyl substituted PAA without LCST and pure water are $7.0 \pm 0.03$. Analogous results have been obtained ${ }^{28,29}$ for the $\mathrm{pH}$ of water in inverted mycelles. $\mathrm{pH}$ is independent of mycelles size but depends on the nature of the functional groups that contact water.

In structure 5, the $\mathrm{OH}^{-}$anion is bound more strongly to the tertiary amide, because the enolic form of the tertiary amide is the most stable. ${ }^{30} \mathrm{H}$-Binding between $\mathrm{H}_{3} \mathrm{O}^{+}$cation and the nitrogen atom of the secondary amide is stronger than in the tertiary amide.

By varying the temperature one brings about changes

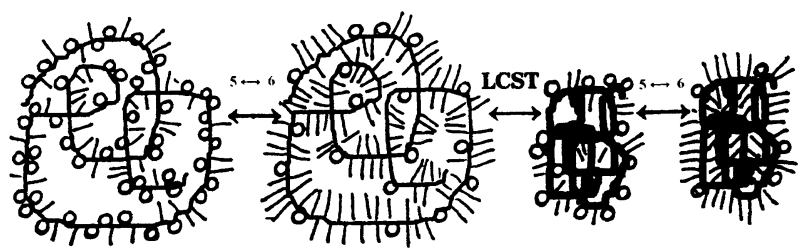

Figure 6. Scheme of micro and macro conformation equilibriums: $\bigcirc$, the cyclic H-bonded structure (5) of the lateral fragments; |, the structure (6) of the lateral fragments.

in IR-transparency (amplitude of the IR-light signal at $4000-400 \mathrm{~cm}^{-1}$ ) of aqueous solutions of polymers with LCST. The IR-transparency of aqueous solutions of polymers without LCST, as well as of pure water is not subject to variation. Obvious changes are completely reversible. As shown in Figure 5, the IR-transparency of aqueous solutions of polymers with LCST linearly decreases as temperature increases. At temperatures close to LCST these solutions clear up due to macromolecular contraction (Figure 6).

\section{DISCUSSION}

Therefore, in solutions of polymers having LCST, there exists probably an equilibrium between at least two conformational structures of lateral fragments of the polymer, one of which (5) controls the solubility of the polymer and the other (6) determines phase separation.

At room temperature (or lower), conformation equilibrium shifts towards cyclic structure $5 . \mathrm{H}_{3} \mathrm{O}^{+}$ cations may interact with nitrogen atoms of neighboring lateral fragments of the polymer, thus stabilizing the ring structure. ${ }^{13}$ In this case, water is involved in the formation of the structure 5 and by forming a well organized structure around an alkyl radical, ${ }^{26,27}$ water induces polarization, stabilizing the positive charge at its surface and thus enabling electrostatic interactions with the $\mathrm{C}=\mathrm{O}$ group of the amide, resulting in increased stability of H-bound cyclic structures. 
Hence, along the entire chain length, lateral fragments are involved into hydrogen bonding and electrostatic interactions, causing the polymer chain to extend. On dissolution, the polymer coil becomes less dense, as confirmed by increased thickness of the "Cold" solid sample (Table IV).

With increase in temperature, $\mathrm{H}$-bonded structures deteriorate, resulting in marked increase of polymer hydrophobicity associated with more perfect separation of the hydrophobic and hydrophilic fragments of a polymer. With increase in temperature, hydrophobic interactions increase. ${ }^{27}$

Effective separation of hydrophobic and hydrophilic fragments of the molecule is more important for decreasing LCST than the incorporation of additional hydrophobic fragments. For $N$-alkyl substituted PMA, LCST is higher than for $N$-alkyl substituted PAA $^{1}$ because of levelling off of hydrophobic-hydrophilic separation.

One can easily explain the effects of structure of alkyl radical in $N$-alkyl substituted PAA on the magnitude of LCST (Table I). Increase in the length of the alkyl radical for more than two carbon atoms, its branching, and introduction of two substituents result in the destabilization of the $\mathrm{H}$-bonded cyclic structure 5 due to thermal motion; consequently, LCST goes down. ${ }^{1}$

Particularly important is that the deterioration of the H-bonded structures 5 («hydrophilic» fragment) and transformation into structures $\mathbf{6}$ («hydrophobic» fragment) result in gradual aggregation and accumulation of hydrophobic lateral fragments around the chain. At certain concentration of the hydrophobic lateral fragments on the chain, the polymer coil drastically changes conformation (contracts). ${ }^{31}$ Hence, phase separation at the critical temperature is preceded by the accumulation of «hydrophobic» fragments. Structures 5 transformation into structures $\mathbf{6}$ after phase separation takes place (Figure 6).

Thus, the presence of hydrophobic and hydrophilic segments in the structure of a polymer is necessary, but not sufficient for the polymer in aqueous solution to show LCST. Copolymers of acrylamide with $N$-octyl acrylamide have no LCST in spite of hydrophilic-hydrophobic balance in the macromolecule. If such a copolymer contains less than $13 \mathrm{~mol} \% \mathrm{~N}$-octyl acrylamide fragments it is soluble in water at any temperature. But if such a copolymer contains more than $13 \mathrm{~mol} \%$ of $N$-octyl acrylamide fragments it is not soluble in water.

Therefore, any copolymer may have LCST if at least one component forms a homopolymer with LCST (for example, $N$-isopropyl acrylamide or $N$-diethyl acrylamide). In this case the copolymerization of such a monomer with hydrophilic or hydrophobic comonomers leads to LCST increase ${ }^{32}$ or decrease. ${ }^{33}$

If in a copolymer the hydrophilic fragment, for example acrylic acid, interacts with a base fragment and as result destabilizes its cyclic $\mathrm{H}$-bonded structure with water (5) the effect of the copolymerization with such hydrophilic comonomers is not evident. ${ }^{34}$

\section{CONCLUSIONS}

Two competitive equilibrium processes are the base of
LCST - the H-bonded cyclic structure formation (decreases the concentration of the "hydrophobic» lateral fragments) and hydrophobic interactions (changes the macromolecular conformation). The first is independent of the second. But the second depends on the first because macromolecule abruptly changes conformation only when hydrophobic lateral fragment concentration is critical.

Acknowledgments. The authors thank Dr. G. N. Bondarenko for making the quantum chemical calculations.

\section{REFERENCES}

1. S. Ito, O. Hirasa, and A. Yamauchi, Kobunshi Ronbunshu, 46, 427 (1989).

2. E. Jehudah, J. Appl. Polym. Sci., 22, 873 (1978).

3. S. Fujishige, Polym. J., 19, 297 (1987).

4. O. Chiantore, M. Guaita, and L. Trossareli, Makromol. Chem., 180, 969 (1979).

5. X. Y. Wu, R. H. Pelton, K. C. Tam, D. R. Woods, and A. E. Hamielec, J. Polym. Sci., 31A, 957 (1993).

6. K. C. Tam, X. Y. Wu, and R. H. Pelton, J. Polym. Sci., 31A, 963 (1993).

7. X. Sh. Wu, A. S. Hoffman, and P. Yager, Makromol. Chem. Rapid Commun., 14, 309 (1993).

8. T. L. Lebedeva, G. A. Shandryuk, T. I. Sycheva, V. S. Bezborodov, R. V. Tal'roze, and N. A. Platé, J. Molec. Struct., 354, 89 (1995).

9. J. Dechant, R. Danz, W. Kimmer, and R. Schmolke, "Ultrarotspektroskopische Untersuchungen on Polymeren," Akademie Verlag, Berlin, 1972, p 258.

10. W. M. Kulicke and R. Kniewske, Makromol. Chem., 181, 823 (1980).

11. K. Ulbrich, L. Cech, J. Kalal, and J. Kopecek, Collec. Czech. Chem. Commun., 42, 2666 (1977).

12. L. J. Bellamy, "The Infra-Red Spectra of Complex Molecules,' Methuen \& Co., Ltd., London, 1954, p 289.

13. V. G. Avakyan, A. D. Litmanovich, and V. O. Cherkezyan, Izv. Akad. Nauk SSSR, Ser. Khim., 329 (1984).

14. W. Shin and S. W. Cho, Acta Crystallogr. C, 48, 1454 (1992).

15. W. A. P. Luck, 'The influence of the electrolytes on the aqueous solutions structure,' in "Water in Polymers," S. P. Rowland, Ed., American Chemical Society, Washington, D.C., 1980.

16. N. B. Librovich, V. P. Sakun, and N. D. Sokolov, 'Sil'nye Vodorodnye Svyaxi v Vodnykh Rastvorakh Kislot i Osnovanii (The Strong Hydrogen Bonds in the Aqueous Solutions of the Acids and the Bases),' in "Vodorodnaya Svyaz (Hydrogen Bond)," N. D. Sokolov, Ed., Nauka, Moscow, 1981, p 174.

17. Y. Marechal, J. Chem. Phys., 95, 5565 (1991).

18. Y. Marechal, J. Chem. Phys., 97, 2846 (1993).

19. K. Rahmelow and W. Hubner, Appl. Spectroscopy, 51, 160 (1997)

20. Z. A. Gabrichidze, Optica i spektroskopiya., 19, 575 (1965).

21. Yu. V. Gurikov, Z. Strukturnoi Khimii., 7, 8 (1966).

22. K. Nakamoto, "Infrared Spectra of Inorganic and Coordination Compaunds," Wiley, New York, London, 1962, pp 109, 124.

23. G. V. Yukhnevich, 'Primenenie infrakrasnoi spektroskopii dlya izucheniya vody $\mathrm{v}$ mineralakh (The IR-spectroscopy use for the study of water in the minerals), in "Svyazannaya Voda $v$ Dispersnykh Sistemakh (Bound Water in Disperse Systems)," Issue 1, Moscow State University, Moscow 1970, p 11.

24. G. V. Yukhnevich, E. G. Tarakanova, V. D. Majorov, and N. B. Librovich, Uspekhi Khimii., 64, 10 (1995).

25. M. Pham Thi, J. F. Herzog, M. H. Herzog-Cance, and A. Potier, J. Molec. Struct., 195, 293 (1989).

26. V. A. Pchelin, 'O strukture vody na granitse s nepolyarnoi sredoi v svyazi s gidrofobnymi vzaimodeistviyami v restvorakh difil'nykh molekul (About the Water Structure on the Bound with Nonpolar Medium in View of the hydrophobic interactions in the Diphilic Molecules Solutions),' in 'Svyazannaya Voda v Dispersnykh Sistemakh (Bound Water in Disperse Systems)," Issue 1, Moscow State University, Moscow 1970, p 74. 
27. G. M. Birshtein, "Sostoyanie i Rol' Vody v Biologicheskikh Ob"ektakh" (The State and Role of Water in Biological Objects), Nauka, Moscow 1967, p 16.

28. A. V. Levashov, V. I. Paitin, and K. Martins, Kolloid-Z., 41, 453 (1979).

29. C. Kumar and D. Balasubmarian, J. Colloid Interface Sci., 74 , 64 (1980).

30. R. T. Morrison and R. N. Boyd, "Organic Chemistry," Allyn \& Bacon, Inc., Boston, 1970.

31. O. O. Maksimenko, M. M. Fel'dshtein, E. E. Panarin, V. P.
Torchilin, A. E. Vasil'ev, and N. A. Platé, Vysokomol. Soedin., 32A, 2362 (1989).

32. L. I. Valuev, O. N. Zefirova, I. V. Obydennova, and N. A. Platé, Vysokomol, Soedin., 35A, 83 (1993).

33. S. N. Popovich, V. V. Chupov, and N. A. Platé, Abstracts of Papers, Int. Conf. on The Fundamental Problems of Polymers Science (At the 90-years of the academician V. A. Kargin), Moscow, 1997, p 2.

34. S. N. Popovich, V. V. Chupov, and N. A. Platé, Vysokomol. Soedin., 396, 2054 (1997). 